\title{
Analisis Pengaruh Beban Pajak Tangguhan, Discretionary Accruals, dan Arus Kas Operasi terhadap Manajemen Laba
}

\author{
Thomas Junior Sibarani ${ }^{1}$, Nur Hidayat ${ }^{2}$, Surtikanti ${ }^{3}$ \\ ${ }^{1}$ Universitas Pancasila, Jl. Srengseng Sawah, Jagakarsa, Jakarta Selatan 12640, \\ ${ }^{2}$ Universitas Jenderal Achmad Yani, Jl. Terusan Jenderal Gatot Subroto, PO BOX 807 Bandung, 40285 \\ ${ }^{3}$ Universitas Komputer Indonesia, Jl. Dipatiukur 112, Bandung
}

I N F O A R T I K E L

JEL Classification:

G14

G30

Keywords:

deferred tax expense,

discretionary accruals,

operating cash flow,

earnings management.

\section{A B S T T R A C T}

The financial statements show the results of management accountability for the use of the resources entrusted to them. This study aims to analyze the probability of occurrence of earnings management. The possibility of earnings management is measured through a variable deferred tax expense, discretionary accruals, and operating cash flow. Analysis was performed on 89 companies listed manufacturing sector in Indonesia Stock Exchange in 2009-2013. Overall the study found empirical evidence that the deferred tax expense, discretionary accruals, and operating cash flow significantly influence the probability of occurrence of earnings management.

\begin{abstract}
A B S T R A K
Laporan keuangan menunjukkan hasil pertanggungjawaban manajemen atas penggunaan sumber daya yang dipercayakan kepada mereka. Penelitian ini bertujuan untuk menganalisis kemungkinan terjadinya manajemen laba. Kemungkinan manajemen laba diukur melalui variabel beban pajak tangguhan, akrual diskresioner, dan arus kas operasi. Analisis dilakukan pada 89 perusahaan yang terdaftar di sektor manufaktur di Bursa Efek Indonesia pada 2009-2013. Secara keseluruhan penelitian ini menemukan bukti empiris bahwa beban pajak tangguhan, akrual diskresioner, dan arus kas operasi berpengaruh secara signifikan terhadap kemungkinan terjadinya manajemen laba.
\end{abstract}

\section{Pendahuluan}

Sebagaimana disebutkan dalam PSAK No. 01 (revisi 2009) paragraf 7, laporan keuangan adalah suatu penyajian terstruktur dari posisi keuangan dan kinerja keuangan suatu entitas. Tujuan laporan keuangan adalah memberikan informasi mengenai posisi keuangan, kinerja keuangan, dan arus kas entitas yang bermanfaat bagi sebagian besar kalangan pengguna laporan dalam pembuatan keputusan ekonomi. Laba merupakan salah satu informasi yang terkandung dalam laporan keuangan yang sangat penting bagi pihak internal maupun eksternal perusahaan. SFAC No.1 menyebutkan bahwa informasi laba pada umumnya merupakan perhatian utama dalam menaksir kinerja atau pertanggungjawaban manajemen dan informasi laba membantu pemilik atau pihak lain melakukan penaksiran atas earnings power perusahaan di masa yang akan datang. Dalam perspektif pengambilan keputusan investasi, informasi laba penting bagi investor untuk mengetahui kualitas laba suatu

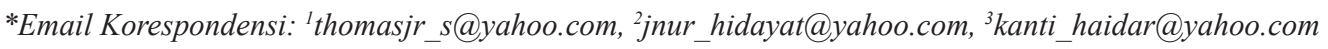


perusahaan sehingga mereka dapat mengurangi risiko informasi.

Adanya fleksibilitas dalam prinsip akuntansi berlaku umum (PABU) menyebabkan terdapat diskresi manajemen dalam akuntansi akrual, Silvia (2002). Diskresi manajerial tersebut dapat meningkatkan kandungan informasi laba karena memungkinkan adanya pengomunikasian informasi privat atau yang disebut efficient earnings management (EEM). Di lain pihak, adanya ketidaksamaan insentif antara manajer dan pemegang saham dapat menyebabkan manajer menggunakan fleksibilitas yang diperbolehkan dalam PABU untuk melakukan earnings management sehingga menciptakan distorsi dalam laba yang dilaporkan atau yang disebut opportunistic earnings management (OEM). Healy dan Wahlen (1999) menyatakan bahwa manajamen laba terjadi ketika manajer menggunakan penilaian dalam pelaporan keuangan, sehingga menyesatkan penilaian stakeholder mengenai kinerja perusahaan atau untuk mempengaruhi hasil kontraktual yang bergantung pada angka akuntansi yang dilaporkan.

Banyak faktor yang memungkinkan terjadinya manajemen laba, yang dalam penelitian ini peneliti ingin menguji variabel beban pajak tangguhan, discretionary accruals, dan arus kas operasi. Secara lebih rinci perumusan masalah ini dibuat dalam empat pertanyaan berikut:

1. Seberapa besar pengaruh beban pajak tangguhan terhadap manajemen laba?

2. Seberapa besar pengaruh discretionary accruals terhadap manajemen laba?

3. Seberapa besar pengaruh arus kas operasi terhadap manajemen laba?

4. Seberapa besar pengaruh beban pajak tangguhan, discretionary accruals, dan arus kas operasi terhadap manajemen laba?

\section{Telaah Teori dan Pengembangan Hipotesis}

\section{Teori Agensi}

Konsep manajemen laba dapat dimulai dari pendekatan teori keagenan. Teori keagenan menyatakan bahwa praktik manajemen laba dipengaruhi oleh adanya konflik kepentingan antara agen (manajemen) dengan prinsipal (pemilik saham) yang timbul ketika setiap kali perusahaan menetapkan rencana dan berusaha untuk mencapai atau mempertahankan tingkat kemakmuran yang dikehendaki. Untuk menilai kinerja manajemen, pemegang saham dapat menggunakan dua ukuran internal dan eksternal. Ukuran kinerja manajemen internal adalah laba, dan ukuran eksternalnya adalah harga saham. Hubungan keagenan ini memberikan ruang bagi terjadinya konflik kepentingan potensial antara manajemen dan pemegang saham. Selain itu, tidak mungkin bagi pemegang saham ataupun manajemen berada pada biaya nol untuk meyakinkan bahwa manajemen akan membuat keputusan optimal dari pandangan pemegang saham sehingga akan memunculkan biaya keagenan (Jensen and Meckling, 1976).

Persoalannya dalam hubungan keagenan, manajer memiliki asimetri informasi terhadap pihak eksternal perusahaan termasuk kreditur dan pemilik saham. Asimetri informasi terjadi ketika manajer memiliki informasi internal perusahaan yang relatif lebuh lengkap, lebih banyak, atau lebih detil dan mengetahui informasi tersebut lebih cepat dibandingkan dengan pihak eksternal. Kondisi ini memberikan kesempatan kepada manajer untuk menggunakan informasi yang diketahuinya untuk memanipulasi laporan keuangan sebagai usaha untuk memaksimalkan kepentingannya. Asimetri informasi pada pasar modal antara lain terlihat dengan adanya biaya transaksi sehubungan dengan informasi yang diberikan.

\section{Beban Pajak Tangguhan}

Pajak tangguhan adalah pajak yang pengakuannya ditangguhkan atau ditunda, sebagai antisipasi terhadap konsekuensi utang pajak penghasilan, baik yang timbul di masa kini maupun di masa depan. Konsep pajak tangguhan berlatar belakang dari perbedaan standard waktu pengakuan dalam pengenaan pajak. Perbedaan perlakukan terhadap pendapatan dan biaya (baik pada saat pengakuan maupun nilainya) sudah pasti akan menimbulkan perbedaan nilai antara 
laba sebelum pajak dengan laba kena pajak (DPP PPh) dalam laporan laba/rugi, yang pada akhirnya juga mengakibatkan perbedaan pada pengakuan utang pajak penghasilan di laporan posisi keuangan. Pendirian yang berlaku umum bagi akuntansi yaitu beban pajak penghasilan merupakan biaya yang seharusnya disandingkan dengan penghasilan yang bersangkutan. Proses yang mengaitkan antara beban pajak penghasilan dengan penghasilan yang bersangkutan dikenal dengan alokasi pajak. Metode alokasi interperiode dapat dilakukan dengan 3 (tiga) cara yaitu metode pajak tangguhan, metode kewajiban, dan metode pajak neto. Menurut PSAK 46, di antara ketiga metode tersebut, hanya metode pajak tanggguhan yang diperkenankan untuk digunakan. Metode pajak tangguhan digunakan karena memperhitungkan alokasi perbedaan temporer yang komprehensif.

\section{Discretionary Accruals}

Menurut DSAK-IAI dalam PSAK 1 (revisi 2009) Penyajian Laporan Keuangan paragrap 25, entitas menyusun laporan keuangan harus atas dasar akrual, kecuali laporan arus kas. Ketika akuntansi berbasis akrual digunakan, entitas mengikuti pos-pos sebagai aset, liabilitas, ekuitas, pendapatan dan beban (unsur-unsur laporan keuangan) ketika pos-pos tersebut memenuhi definisi dan kriteria pengakuan untuk unsur-unsur teresebut dalam Kerangka Dasar Penyusunan dan Penyajian Laporan Keuangan (PSAK 1, revisi 2009, paragraf 26). Oleh sebab itu akuntansi berbaris akrual didefinisikan sebagai suatu basis akuntansi dimana transaksi ekonomi dan peristiwa lainnya diakui, dicatat, dan disajikan dalam laporan keuangan pada saat terjadinya transaksi tersebut, tanpa memperhatikan waktu kas atau setara kas yang diterima atau dibayarkan. Dalam akuntansi berbasis akrual, waktu pencatatan sesuai dengan waktu terjadinya arus sumber daya, sehingga dapat menyediakan informasi yang paling komprehensif, karena seluruh arus sumber daya dicatat. Barth, Cram dan Nelson (2001) mengemukakan bahwa akrual dan komponen agregatnya berguna untuk memprediksi arus kas masa depan perusahaan.
Akrual menginformasikan harapan arus kas masa depan yang berhubungan dengan arus kas masa depan yang lebih tinggi. Depresiasi aset tetap dan amortisasi aset tidak berwujud berhubungan dengan arus kas masa depan yang lebih tinggi. Hal ini berarti, komponen akrual dari arus kas operasi seharusnya menyediakan informasi yang berguna untukmemrediksikemampuanperusahaanbangkit dari kesulitan keuangan. Model modified Jones merupakan modifikasi dari model Jones yang didesain untuk mengeliminasi kecenderungan untuk menggunakan perkiraan yang bisa salah dari model Jones untuk menentukan discretionary accruals ketika discretion melebihi pendapatan. Model ini banyak digunakan dalam penelitianpenelitian akuntansi karena dinilai merupakan model yang paling baik dalam mendeteksi manajemen laba.

\section{Arus Kas Operasi}

Laporanaruskasmenyajikan dasaranalisis dinamis yang berpusat pada periode perubahan kondisi keuangan akibat keputusan yang diambil selama periode tertentu. Laporan arus kas merupakan penyajian informasi tentang jumlah arus kas masuk dan arus kas keluar atau sumber dan pemakaian kas dalam suatu perusahaan. Laporan arus kas harus melaporkan arus kas selama periode tertentu dan diklasifikasikan menurut aktivitas operasi, investasi, dan pendanaan. Sebagaimana diungkapkan Kieso (2013), laporan arus kas merupakan salah satu dari empat elemen laporan keuangan, dimana elemen lainnya adalah laporan posisi keuangan, laporan laba rugi, dan laporan perubahan ekuitas. Laporan arus kas melaporkan: (i) pengaruh operasi suatu perusahaan atas kas selama satu periode; (ii) transaksi investasinya; (iii) transaksi pembelanjaan; (iv) transaksi kenaikan atau penurunan bersih dalam kas selama satu periode. Tujuan laporan arus kas adalah memberikan informasi yang relevan mengenai penerimaan dan pembayaran kas dari suatu perusahaan selama satu periode.

\section{Manajemen Laba}

Laba rugi komprehensif sebagaimana 
dalam PSAK 1 (revisi 2009) Penyajian Laporan Keuangan adalah perubahan ekuitas selama satu periode yang dihasilkan dari transaksi dan peristiwa lainnya, selain perubahan yang dihasilkan dari transaksi dengan pemilik dalam kapasitasnya sebagai pemilik. Informasimengenai laba sebagai bagian dari laporan keuangan, sering menjadi target rekayasa melalui tindakan oportunis manajemen untuk memaksimalkan kepuasannya namun di lain pihak dapat merugikan stakeholders lainnya termasuk pemegang saham, kreditur, dan investor. Terbukanya fleksibilitas dalam implementasi prinsip akuntansi yang berlaku umum menyebabkan manajemen dapat memilih kebijakan akuntansi dari berbagai pilihan kebijakan yang ada, sehingga fleksibilitas ini memungkinkan pula dilakukannya pengelolaan laba oleh manajemen perusahaan. Sejumlah peneliti berpendapatbahwa earnings management dapat menguntungkan karena berpotensi untuk meningkatkan nilai informasi laba. Manajer dapat menggunakan diskresi mereka atas laba untuk mengomunikasikan infomasi privat kepada para pemegang saham dan publik. Oleh karena itu, earnings management dapat bersifat oportunistik (opportunistic earnings management/OEM) atau bersifat efisien (efficient earnings management/ EEM). Ada alasan mendasar mengapa manajer melakukan manajemen laba. Harga pasar saham suatu perusahaan secara signifikan dipengaruhi oleh laba, risiko, dan spekulasi. Oleh sebab itu, perusahaan yang labanya selalu mengalami kenaikan dari periode ke periode secara konsisten akan mengakibatkan risiko perusahaan mengalami penurunan lebih besar dibandingkan persentase kenaikan laba.

Dipandang dari sudut pandang moral (etika), Merchant dan Rockness (1994) mendefiniskikan earnings management sebagai tindakan yang dilakukan oleh manajemen sebuah perusahaan dengan cara memanipulasi laba, sehingga memberikan informasi mengenai keuntungan ekonomis (economic advantage) yang sesungguhnya tidak dialami oleh perusahaan tersebut. Tindakan manajamen untuk melakukan manajemen laba, dapat dikategorikan sebagai suatu penipuan dan tidak etis. Manajemen laba merupakan intervensi manajemen dalam proses pelaporan keuangan dengan tujuan untuk menguntungkan dirinya sendiri. Adapun polapola manajemen laba, sebagaimana menurut Scott (2005) adalah taking a bath, income maximation, income minimation, income smoothing.

\section{Penelitian Terdahulu}

PenelitianYulianti(2005)mengujikorelasi antara CFO dengan akrual dan variabel beban pajak tangguhan diukur dengan menganalisis perubahan yang terjadi atas aktiva pajak tangguhan dan kewajiban pajak tangguhan yang dilaporkan perusahaan dalam laporan keuangan tahun berjalan. Penelitian ini menemukan bahwa kedua pengukur manajemen laba (akrual dan beban pajak tangguhan) memiliki pengaruh yang positif dan signifikan terhadap probabilitas perusahaan melakukan manajemen laba untuk menghindari kerugian. Walaupun demikian, dalam model yang digunakan, variabel beban pajak tangguhan dapat menjelaskan probabilitas perusahaan melakukan manajemen laba dengan tingkat keyakinan yang lebih tinggi dibandingkan model discretionary accrual (tingkat keyakinan untuk beban pajak tangguhan adalah sebesar $95 \%$ dan untuk model discretionary accrual sebesar 90\%).

Penelitian Wiryandari et al (2009) menguji probabilita beban pajak tangguhan dalam mendeteksi manajemen laba adalah equity market yaitu laba bersih dibagi dengan nilai pasar ekuitas awal tahun yang menunjukkan ekspektasi pasar terhadap laba yang dilaporkan perusahaan. Penelitian ini menemukan bahwa memang terjadi manajemen laba dengan tujuan menghindari pelaporan kerugian pada perusahaan-perusahaan yang terdaftar di BEI. Penemuan ini didasari uji statistik dan histogram atas distribusi laba dan manajemen laba terbukti ada dengan terpatahnya distribusi laba di sekitar titik nol (ambang batas pelaporan laba). Namun penelitian ini tidak menemukan adanya manajemen laba dengan tujuan menghindari pelaporan penurunan laba. Penelitian Subagyo et al (2011) menguji pengaruh discretionary accrual dan beban pajak tangguhan terhadap manajemen laba. Penelitian ini menemukan bahwa variabel 
discretionary accrual tidak berpengaruh signifikan terhadap kemungkinan perusahaan melakukan manajemen laba. Variabel beban pajak tangguhan berpengaruh

negatif dan signifikan terhadap kemungkinan perusahaan melakukan manajemen laba.

Berdasarkan berbagai hasil penelitian terdahulu yang ternyata menunjukkan hasil yang berbeda-beda, maka peneliti mengajukan hipotesis sebagai berikut.

Hipotesis 1 : Beban pajak tangguhan berpengaruh signifikan terhadap manajemen laba

Hipotesis 2 : Discretionary accruals berpengaruh signifikan terhadap manajemen laba

Hipotesis 3 : Arus kas operasi berpengaruh signifikan terhadap manajemen laba

Hipotesis 4 : Beban pajak tangguhan, discretionary accruals, dan arus kas operasi berpengaruh signifikan terhadap manajemen laba

Keempat hipotesis tersebut tergambar pada gambar 1 framework of theory.

\section{Metode}

Menurut sifatnya, data dalam penelitian ini mencakup data kuantitatif, yakni data yang di nyatakan dalam bentuk angka atau skala (numerik); maupun data kualitatif, yakni data yang tidak berbentuk angka yang tidak dapat diukur dengan skala numerik, sehingga disebut data non-numerik. Menurut sumbernya, data dalam penelitian ini terdiri dari data internal, yakni data yang bersumber dari keadaan atau kegiatan suatu organisasi atau kelompok; dan data eksternal, yakni data yang bersumber dari luar organisasi atau kelompok. Dilihat dari teknik memperolehnya, data dalam penelitian ini terdiri dari data primer, yakni data yang dikumpulkan dan diolah sendiri oleh suatu organisasi atau perseorangan langsung dari objeknya; dan data sekunder, yakni data yang diperoleh dalam bentuk jadi dan telah diolah oleh pihak lain yang biasanya dalam bentuk publikasi. Dalam penelitian ini data sekunder diperoleh dengan mempelajari dokumen yang terkait dengan objek penelitian, hingga studi kepustakaan (library research) dengan mempelajari teori, penelitian terdahulu, kajian, serta berita yang terkait dengan objek penelitian. Sedangkan menurut waktu pengumpulannya, data dalam penelitian ini bukanlah data runtut waktu atau data berkala (time series), namun data silang tempat atau cross-section, yakni data yang dikumpulkan hanya dalam suatu periode tertentu.

Dalam penelitian ini yang dimaksud populasi adalah 148 perusahaaan (emiten) sektor industri manufaktur yang terdaftar di Bursa Efek

\section{Gambar 1}

\section{Kerangka Pikir}

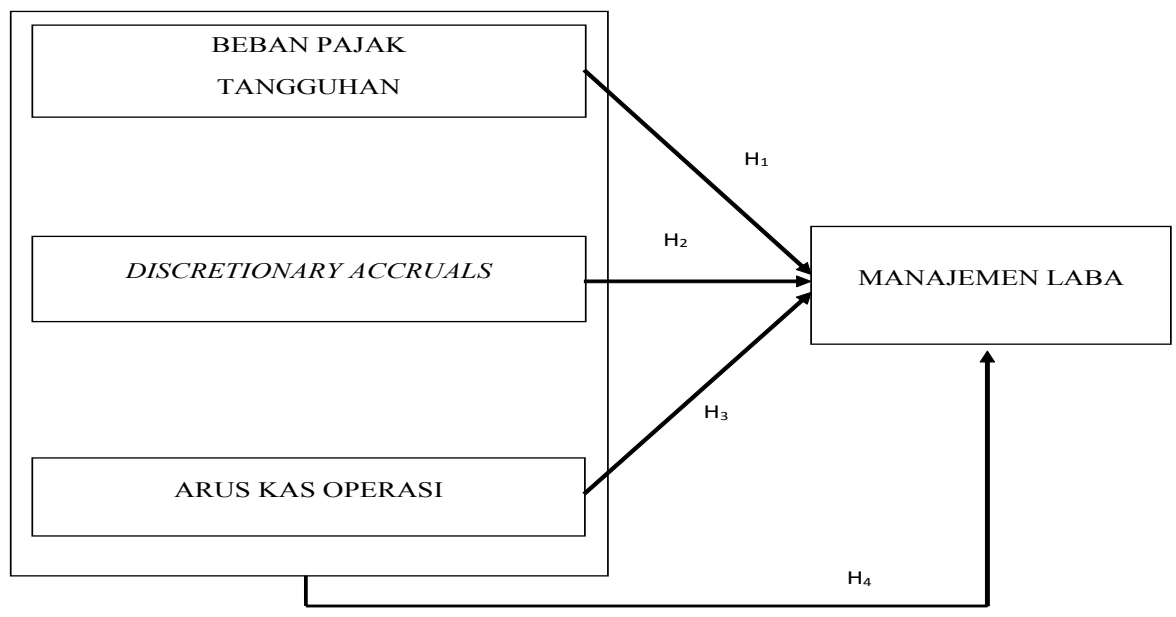


Indonesia. Teknik pengambilan sampel dalam penelitian ini adalah purposive sampling methods di mana informasi yang ingin didapatkan dalam penelitian diperoleh dari target atau kelompok yang bersifat spesifik dan memenuhi kriteria yang ditetapkan oleh peneliti di mana dari populasi yang tersedia akan dipilih berdasarkan kriteria-kriteria sebagai berikut : (1) Perusahaan industri manufaktur yang terdaftar di BEI selama tahun 2009 sampai dengan tahun 2013, (2) Perusahaan terdaftar sebelum 1 Januari 2008, (3) Perusahaan menggunakan mata uang rupiah dalam laporan keuangannya, (4) Perusahaan tidak pernah delisting selama periode pengamatan, (5) Perusahaan memiliki laporan keuangan lengkap selama periode pengamatan, (6) Perusahaan memiliki data yang lengkap terkait dengan variabel-variabel yang digunakan dalam penelitian ini. Sebelum dilakukan pengujian hipotesis pertama sekali dilakukan analisis deskriptif untuk memberikan gambaran umum mengenai data penelitian. Statistik deskriptif memberikan gambaran atau deskripsi suatu data yang dilihat dari nilai minimum, maksimum, ratarata (mean), dan standard deviasi. Hasil pengujian menunjukkan jumlah sampel yang digunakan apakah ada data yang hilang (missing cases) ataupun data yang tidak terseleksi (unselected cases).

\section{Model Logistic Regression}

1. Pengujian overall model fit

Langkah pertama adalah menilai overall model fit terhadap data. Beberapa pengujian diberikan untuk menilai hal ini. Statistik yang digunakan berdasarkan pada fungsi likelihood. Likelihood L dari model adalah probabilitas bahwa model yang dihipotesiskan menggambarkan data input. Untuk menguji hipotesis nol dan hipotesis alternatif, L ditransformasikan menjadi $-2 \log L(-2 \log$ Likelihood).

$$
G=-2 \log \left(\frac{l_{0}}{l_{1}}\right)=-2\left[\log \left(l_{0}\right)-\log \left(l_{1}\right)\right]=-2\left(L_{0}-L_{1}\right)
$$

\section{Keterangan:}

$1_{0}=$ nilai maksimum fungsi kemungkinan untuk model di bawah hipotesis nol
$1_{1}=$ nilai maksimum fungsi kemungkinan untuk model di bawah hipotesis alternatif

$\mathrm{L}_{0}=$ nilai maksimum fungsi log kemungkinan untuk model di bawah hipotesis nol

$\mathrm{L}_{1}=$ nilai maksimum fungsi log kemungkinan untuk model di bawah hipotesis nol

2. Pengujian kelayakan model regresi

a. Hosmer and Lameshow goodness of fit test model

Alat yang digunakan untuk menguji kecocokan model dalam regresi logistik adalah uji Hosmer-Lameshow. Statistik Hosmer-Lameshow mengikuti distribusi chisquare dengan $\mathrm{df}=\mathrm{g}-2$ di mana g adalah banyaknya kelompok dengan rumusan sebagai berikut.

$$
\chi_{H L}^{2}=\sum_{i=1}^{g} \frac{\left(O_{i}-N_{i} \bar{\pi}_{i}\right)^{2}}{N_{i} \bar{\pi}_{i}\left(1-\bar{\pi}_{i}\right)}
$$

Keterangan:

$$
\begin{aligned}
& \mathrm{N}_{\mathrm{i}}=\begin{array}{l}
\text { Total frekuensi pengamatan } \\
\text { kelompok ke- } \mathrm{i}
\end{array} \\
& \mathrm{O}_{\mathrm{i}}=\begin{array}{l}
\text { Frekuensi pengamatan kelompok } \\
\text { ke- } \mathrm{i}
\end{array} \\
& \pi_{\mathrm{i}}=\begin{array}{l}
\text { Rata-rata tafsiran peluang } \\
\text { kelompok ke- } \mathrm{i}
\end{array}
\end{aligned}
$$

Model ini ditujukan untuk menguji apakah data empiris cocok atau sesuai dengan model. Apabila nilai signifikansi lebih besar dari pada alpha 5\% maka secara statistik tidak terdapat perbedaan yang signifikan antara model dengan nilai observasi yang berarti model regresi logistik dapat digunakan untuk memenuhi kecukupan data.

b. Pengujian ketepatan prediksi

Pengujian ini dilakukan untuk menguji ketepatan model dalammemrediksiklasifikasi dengan membandingkan antara nilai prediksi dan observasi dalam classification table. Cox and Snell's $R$ Square dan Nagelkerke's $R$ Square

Nilai Cox and Snell's $R$ Square dan Nagelkerke's $R$ Square pada multiple regression dilambangkan dengan $\mathrm{R}$ square 
dan digunakan untuk melihat besarnya pengaruh variabel bebas terhadap variabel terikat. Pengujian ini dilakukan untuk menganalisis kemampuan variabel beban pajak tangguhan, discretionary accruals, dan arus kas operasi menjelaskan probabilitas terjadinya manajemen laba.

c. Cox and Snell's R Square dan Nagelkerke's R Square

Nilai Cox and Snell's R Square dan Nagelkerke's $R$ Square pada multiple regression dilambangkan dengan $\mathrm{R}$ square dan digunakan untuk melihat besarnya pengaruh variabel bebas terhadap variabel terikat. Pengujian ini dilakukan untuk menganalisis kemampuan variabel beban pajak tangguhan, discretionary accruals, dan arus kas operasi menjelaskan probabilitas terjadinya manajemen laba.

d. Estimasi parameter dan interpretasi

Pengujian ini dilakukan untuk melihat seberapa besar pengaruh variabel bebas terhadap variabel terikat dengan melihat tingkat signifikansi masing-masing variabel. Uji signifikansi parameter secara individual dilakukan dengan menggunakan Wald test dengan uji statistik sebagai berikut.

$$
W^{2}=\left[\frac{\hat{\beta}_{i}}{S E\left(\hat{\beta}_{i}\right)}\right]
$$

e. Omnibus Test of Model Coefficient

Model ini untuk menguji tingkat signifikansi variabel beban pajak tangguhan, discretionary accruals, dan arus kas operasi secara bersamasama memiliki pengaruh yang signifikan terhadap manajemen laba.

f. Pengujian korelasi antar-variabel independen

Pengujian ini bertujuan untuk megetahui apakah terdapat korelasi antar-variabel independen. Apabila besarnya korelasi tersebut masih dibawah 95\% maka dapat dikatakan tidak terjadi multikolinearitas.

Regresi logistik menghasilkan rasio peluang yang dinyatakan dengan transformasi fungsi logaritma (log) sehingga dengan demikian fungsi transformasi $\log$ ataupun $\ln$ diperlukan untuk p-value. Untuk itu dapat dinyatakan bahwa logit(p) merupakan log dari peluang (odds ratio) atau likelihood ratio dengan kemungkinan terbesar nilai peluang adalah 1. Persamaan regresi logistik menjadi:

$$
\operatorname{logit}(\mathrm{p})=\log (\mathrm{p} / 1-\mathrm{p})=\ln (\mathrm{p} / 1-\mathrm{p})
$$

di mana $\mathrm{p}$ bernilai antara $0-1$.

Model yang digunakan pada regresi logistik adalah:

$\log (\mathrm{p} / 1-\mathrm{p})=\beta_{0}+\beta_{1} \mathrm{X}_{1}+\beta_{2} \mathrm{X}_{2}+\beta_{3} \mathrm{X}_{3}+\ldots+$ $\beta_{k} X_{k}$

Keterangan:

$\mathrm{p}=$ kemungkinan bahwa $\mathrm{Y}=1$

$\beta=$ Koefisien regresi

$\mathrm{X}=$ variabel independen

Untuk Definisi Operasional dari masing-masing variabel adalah sebagai berikut :

1. Beban pajak tangguhan $\left(\mathrm{X}_{1}\right)$

Beban pajak tangguhan adalah beban yang timbul akibat perbedaan antara laba akuntansi yaitu laba laporan keuangan untuk kepentingan pihak eksternal dengan laba fiskal yaitu laba yang dipergunakan sebagai dasar perhitungan pajak. Perbedaan antara laporan keuangan, standar akuntansi dan fiskal disebabkan dalam penyusunan laporan keuangan, standar akuntansi lebih memberikan keleluasaan bagi manajemen dalam menentukan prinsip dan asumsi dibandingkan dengan yang diperbolehkan menurut pajak. Perhitungan tentang beban pajak tangguhan dihitung dengan menggunakan indikator membobot beban pajak tangguhan dengan total aktiva atau total aset. Hal ini dilakukan untuk pembobotan beban pajak tangguhan dengan total aset pada periode $\mathrm{t}-1$ untuk memperoleh nilai yang terhitung dengan proporsional.

DTE $_{\text {it }}=\left(\right.$ beban pajak tangguhan $\left._{t}\right) /\left(\right.$ total aset $\left._{\mathrm{t}-1}\right)$

\section{Discretionary accruals $\left(\mathrm{X}_{2}\right)$}

Dalam akuntansi dikenal istilah basis akrual dan basis kas. Istilah digunakan untuk menentukan penghasilan pada saat diperoleh dan untuk mengakui beban yang sepadan dengan revenue pada periode yang sama tanpa 
memperhatikan waktu penerimaan kas dari penghasilan yang bersangkutan. Komponen akrual merupakan perngakuan kejadian non-kas dalam laporan laba rugi namun diharapkan akan diterima atau dibayarkan biasanya dalam kas di masa yang akan datang (Belkaoui, 2007). Dalam penelitian ini variabel akrual diproksi dengan discretionary accruals dari model modified Jones yang merupakan model terbaik untuk mendeteksi manajemen laba (Suranggane, 2007) dan model ini mengeluarkan variabel arus kas operasi (cash flows from operation / CFO) untuk meghindari multikolinearitas.

$$
\begin{aligned}
\mathrm{DA}_{\mathrm{it}}= & \mathrm{TAcc}_{\mathrm{it}}-\left(\alpha+\beta_{1}\left(\Delta \mathrm{Sales}_{\mathrm{it}}-\Delta \mathrm{AR}_{\mathrm{it}}\right)+\right. \\
& \beta_{2} \mathrm{PPE}_{\mathrm{it}}+\varepsilon_{\mathrm{it})} \\
& \text { Adapun cara untuk menghitung }
\end{aligned}
$$
discretionary accruals dengan model modified Jones terdiri dari beberapa tahapan sebagai berikut.

a. Total accruals merupakan penjumlahan dari discretionary accruals dan non-discretionary accruals yang dapat digambarkan dengan persamaan:

$\mathrm{TAcc}_{\mathrm{it}}=\mathrm{DA}_{\mathrm{it}}+\mathrm{NDA}_{\mathrm{it}}$

Keterangan:

$\mathrm{TAcc}_{\mathrm{it}}=$ total accruals perusahaan $\mathrm{i}$ periode $\mathrm{t}$

$\mathrm{DA}_{\mathrm{it}} \quad=$ discretionary accruals perusahaan i periode $\mathrm{t}$

$\mathrm{NDA}_{\mathrm{it}}=$ non-discretionary accruals perusahaan periode $\mathrm{t}$

b. Menghitung total accruals dengan persamaan:

$$
\mathrm{TAcc}_{\mathrm{it}}=\mathrm{NI}_{\mathrm{it}}-\mathrm{CFO}_{\mathrm{it}}
$$

Keterangan:

$$
\begin{array}{ll}
\text { TAcc }_{\mathrm{it}} \quad= & \text { total accruals perusahaan } \mathrm{i} \\
& \text { periode } \mathrm{t} \\
\mathrm{NI}_{\mathrm{it}} & =\text { net income perusahaan } \mathrm{i} \\
& \text { periode } \mathrm{t} \\
\mathrm{CFO}_{\mathrm{it}} \quad= & \text { cash flow from operation } \\
& \text { perusahaan i periode } \mathrm{t}
\end{array}
$$

c. Menghitung koefisien dengan melakukan regresi terhadap persamaan:

$$
\frac{\mathrm{TAcc}_{i t}}{\mathrm{TA}_{\mathrm{t}-1}}=\alpha \frac{1}{\mathrm{TA}_{\mathrm{t}-1}}+\beta 1 \frac{\left(\Delta \text { Sales }_{i t}-\Delta \mathrm{AR}_{\mathrm{it}}\right)}{\mathrm{TA}_{\mathrm{t}-1}}+\beta 2 \frac{\mathrm{PPE}_{\mathrm{it}}}{\mathrm{TA}_{\mathrm{t}-1}}+\varepsilon_{\mathrm{it}}
$$

Keterangan:

$\mathrm{TAcc}_{\mathrm{it}}=$ total accruals perusahaan $\mathrm{i}$ periode $\mathrm{t}$

$\Delta$ Sales $_{\text {it }}=$ penjualan perusahaan $\mathrm{i}$ periode $\mathrm{t}$

$\Delta \mathrm{AR}_{\mathrm{it}}=$ piutang perusahaan $\mathrm{i}$ periode $\mathrm{t}$

$\mathrm{PPE}_{\mathrm{it}}=$ plant, property, and asset perusahaan i periode $\mathrm{t}$

$\mathrm{TA}_{\mathrm{t}-1}=$ total aset perusahaan $\mathrm{i}$ periode $\mathrm{t}-1$

$\alpha, \beta_{1}, \beta_{2}=$ koefisien

d. Koefisien $\alpha, \beta_{1}, \beta_{2}$ yang diperoleh dari regresi tersebut digunakan untuk mendapatkan nilai non-discretionary accruals dalam persamaan:

$$
\mathrm{NDA}_{\mathrm{it}}=\alpha+\boldsymbol{\beta}_{1}\left(\Delta \text { Sales }_{\mathrm{it}}-\Delta \mathrm{AR}_{\mathrm{it}}\right)+\boldsymbol{\beta}_{2} \mathrm{PPE}_{\mathrm{it}}+\varepsilon_{\mathrm{it}}
$$

Keterangan:

$$
\begin{aligned}
& \mathrm{NDA}_{\mathrm{it}}=\text { non-discretionary accruals } \\
& \text { perusahaan i periode } \mathrm{t} \\
& \Delta \text { Sales }_{\mathrm{it}}=\text { penjualan perusahaan } \mathrm{i} \\
& \text { periode } \mathrm{t} \\
& \Delta \mathrm{AR}_{\mathrm{it}}=\text { piutang perusahaan i periode } \mathrm{t} \\
& \mathrm{PPE}_{\mathrm{it}}=\text { plant, property, and asset } \\
& \text { perusahaan i periode } \mathrm{t} \\
& \alpha, \beta_{1}, \beta_{2}=\text { koefisien }
\end{aligned}
$$

e. Nilai discretionary accruals diperoleh dari selisih total accruals dan non-discretionary accruals dengan persamaan:

$$
\begin{aligned}
\mathbf{D A}_{\mathrm{it}}= & \text { TAcc }_{\mathrm{it}}-\left(\alpha+\beta_{1}\left(\Delta \text { Sales }_{\mathrm{it}}-\Delta \mathrm{AR}_{\mathrm{it}}\right)+\boldsymbol{\beta}_{2} \mathbf{P P E}_{\mathrm{it}}\right. \\
& +\varepsilon_{\mathrm{it})}
\end{aligned}
$$

Keterangan:

$$
\begin{aligned}
\mathrm{DA}_{\mathrm{it}}= & \text { discretionary accruals } \\
\mathrm{TAcc}_{\mathrm{it}}= & \text { perusahaan } \mathrm{i} \text { pada periode } \\
& \mathrm{t} \\
& \begin{array}{l}
\text { total accruals perusahaan } \\
\text { i pada periode } \mathrm{t}
\end{array} \\
\Delta \text { Sales }_{\mathrm{it}}= & \begin{array}{l}
\text { perubahan sales revenue } \\
\text { perusahaan } \mathrm{i} \text { tahun } \mathrm{t} \\
\\
\text { dengan tahun } \mathrm{t}-1
\end{array}
\end{aligned}
$$




$$
\begin{aligned}
& \Delta \mathrm{AR}_{\mathrm{it}}=\begin{array}{l}
\text { perubahan piutang } \\
\text { dagang perusahaan } \mathrm{i}
\end{array} \\
& \text { tahun } \mathrm{t} \text { dengan tahun } \mathrm{t}-1 \\
& \mathrm{PPE}_{\mathrm{it}}=\begin{array}{l}
\text { gross property plant } \\
\text { equipment perusahaan } \mathrm{i}
\end{array} \\
& \text { tahun } \mathrm{t} \\
& \alpha \beta 1 \beta 2=\begin{array}{l}
\text { estimasi non- } \\
\text { discretionary accruals }
\end{array} \\
& \varepsilon_{\mathrm{it}}=\text { error term }
\end{aligned}
$$

\section{Arus kas operasi $\left(\mathrm{X}_{3}\right)$}

Arus kas operasi merupakan penerimaan dan pengeluaran kas suatu perusahaan dan untuk aktivitas operasi selama satu periode. Arus kas dari aktivitas operasi terutama diperoleh dari aktivitas penghasil utama pendapatan perusahaan. Oleh karena itu, arus kas tersebut pada umumnya berasal dari transaksi dan peristiwa lain yang mempengaruhi penetapan laba atau rugi bersih. Komponen arus kas operasi sesuai dengan yang didefinisikan dalam PSAK No. 2 (revisi 2009) tentang Laporan Arus Kas. Perubahan arus kas operasi diukur dengan perubahan nilai arus kas operasi perusahaan i pada akhir periode $t$ dengan $\mathrm{t}-1$ dibagi dengan total aset pada tahun $\mathrm{t}-1$.

$$
\Delta \mathrm{CFO}=\left(\mathrm{CFO}_{\mathrm{it}}-\mathrm{CFO}_{\mathrm{it}-1}\right) /\left(\text { Total assets }_{\mathrm{it}-1}\right)
$$

4. Manajemen laba (Y)

Manajemen laba adalah intervensi atau campur tangan manajemen dalam proses pelaporan keuangan eksternal dengan tujuan untuk menguntungkan dirinya sendiri. Earnings management merupakan salah satu yang dapat mengurangi kredibilitas laporan keuangan, Setiawati dan Na'im (2000). Dalam hal ini manajemen berusaha memaksimalkan kesejahteraannya dengan meningkatkan kinerja melalui peningkatan laba dengan segera dengan cara-cara yang tidak wajar dan tidak sesuai dengan kepentingan pemegang saham. Earnings management berhubungan erat dengan tingkat perolehan laba (earnings) atau prestasi usaha suatu organisasi. Itulah sebabnya para manajer atau pimpinnan perusahaan sering berusaha menonjolkan prestasinya melalui earnings management. Dalam penelitian ini manajemen laba diukur dengan menggunakan variabel dan pengukuran untuk distribusi laba sebagai ketentuan kategori perusahaan melakukan manajemen laba sesuai dengan penelitian yang dilakukan Yulianti (2005).

$$
\mathrm{EM}=\mathrm{NI}_{\mathrm{it}} /\left(\mathrm{MVE}_{\mathrm{it}-1}\right)
$$

Keterangan:

$$
\begin{aligned}
& \mathrm{EM}=\text { earnings management } \\
& \mathrm{NI}_{\mathrm{it}}=\text { net income perusahaan i periode } \\
& \mathrm{t} \\
& \mathrm{MVE}_{\mathrm{it}-1}=\text { market value of equity } \\
& \text { perusahaan i periode } \mathrm{t}-1
\end{aligned}
$$

Metode analisis yang digunakan dalam penelitian ini adalah uji statistik deskriptif dan uji hipotesis dengan menggunakan regresi logistik. Model regresi logistik yang akan digunakan pada penelitian ini untuk menguji hipotesis yang diajukan adalah sebagai berikut.

$$
\operatorname{Ln} \frac{E M}{1-E M}=\alpha+\beta 1 D T E i t+\beta 2 D A i t+\beta 3 \Delta C F \text { Oit }+\varepsilon
$$

Keterangan:

Ln $\frac{E M}{1-E M}$ = variable dummy kategori untuk kategori small profit firms dan kode 0 untuk small loss firms

$$
\begin{aligned}
& \alpha=\text { Konstanta } \\
& \beta=\text { koefisien masing-masing } \\
& \text { variabel } \\
& \text { DTE }_{\text {it }}=\text { beban pajak tangguhan } \\
& \text { perusahaan i pada periode } \mathrm{t} \\
& \mathrm{DA}_{\mathrm{it}}=\text { besaran discretionary accruals } \\
& \text { perusahaan i pada periode } t \\
& \text { dengan menggunakan model } \\
& \text { modified Jones } \\
& \Delta \mathrm{CFO}_{\mathrm{it}}=\text { cash flow from operations } \\
& \text { perusahaan i pada periode } \mathrm{t} \\
& \text { E }=\text { error term }
\end{aligned}
$$

\section{Hasil Penelitian dan Pembahasan}

Analisis data dalam penelitian ini menggunakan 89 perusahaan yang dipilih dengan metode purposive sampling, dengan kriteria yang telah di tentukan. Proses pemilihan sampel disajikan pada tabel 1 
Tabel 1

Proses Seleksi Sampel

\begin{tabular}{clc}
\hline No. & \multicolumn{1}{c}{ Kriteria } & Jumlah \\
\hline 1 & $\begin{array}{l}\text { Perusahaan industri manufaktur yang terdaftar di BEI selama tahun 2009 sampai dengan } \\
\text { tahun } 2013\end{array}$ & 144 \\
2 & Perusahaan terdaftar sebelum 1 Januari 2008 & 122 \\
3 & Perusahaan menggunakan mata uang rupiah dalam laporan keuangannya & 97 \\
4 & Perusahaan tidak pernah delisting selama periode pengamatan & 93 \\
5 & Perusahaan memiliki laporan keuangan lengkap selama periode pengamatan & 89 \\
6 & $\begin{array}{l}\text { Perusahaan memiliki data yang lengkap terkait dengan variabel-variabel yang digunakan } \\
\text { dalam penelitian ini }\end{array}$ & 89 \\
\hline
\end{tabular}

Untuk Hasil dari Pengujian kelayakan model regresi adalah sebagai berikut :

1. Hosmer and Lameshow goodness of fit test model

Hasil menunjukkan bahwa nilai signifikansi 0,125 lebih besar dari pada alpha $5 \%$ sehingga secara statistik tidak terdapat perbedaan yang signifikan antara model dengan nilai observasi yang berarti model regresi logistik dapat digunakan untuk memenuhi kecukupan data.

2. Pengujian ketepatan prediksi

Pada tabel 2 hasil menunjukkan bahwa diketahui secara keseluruhan ketepatan model dalam memprediksi klasifikasi adalah sebesar $67,6 \%$.

3. Cox and Snell's $R$ Square dan Nagelkerke's $R$ Square
Tabel 3 menunjukkan hasil pengolahan data dengan model regresi logistik menghasilkan R square sebesar 0,104 dengan nilai -2 Log Likelihood sebesar 533,903. Nagelkerke's R Square sebesar 0,104 memiliki arti bahwa manajemen laba dapat dijelaskan oleh beban pajak tangguhan, discretionary accruals, dan arus kas operasi sebesar 10,4\% sedangkan sisanya dijelaskan oleh faktor-faktor lain yang tidak terdapat dalam model penelitian.

4. Estimasi parameter dan interpretasi

Pengujian ini dilakukan untuk melihat seberapa besar pengaruh variabel bebas terhadap variabel terikat dengan melihat tingkat signifikansi masing-masing variabel. Hasil pengujian estimasi parameter dan interpretasi adalah seperti pada tabel 4 .

Tabel 2

Hasil Pengujian Ketepatan Prediksi

Classification Table ${ }^{\mathrm{a}}$

\begin{tabular}{|c|c|c|c|c|c|}
\hline & \multirow{3}{*}{ Observed } & & \multicolumn{3}{|c|}{ Predicted } \\
\hline & & & \multicolumn{2}{|c|}{ DummyEM } & \multirow{2}{*}{$\begin{array}{c}\text { Percentage } \\
\text { Correct }\end{array}$} \\
\hline & & & $\mathbf{0}$ & 1 & \\
\hline \multirow{3}{*}{ Step 1} & \multirow{2}{*}{ DummyEM } & 0 & 21 & 129 & 14,0 \\
\hline & & 1 & 15 & 280 & 94,9 \\
\hline & \multicolumn{2}{|c|}{ Overall Percentage } & & & 67,6 \\
\hline
\end{tabular}


Tabel 3

Hasil Pengujian Cox and Snell's R Square dan Nagelkerke's R Square

\begin{tabular}{lccr}
\hline \multicolumn{3}{c}{ Model Summary } \\
\hline Step & -2 Log likelihood & $\begin{array}{c}\text { Cox \& Snell } \\
\text { R Square }\end{array}$ & Nagelkerke R Square \\
\hline 1 & $533,903^{\text {a }}$ & &, 075 \\
\hline
\end{tabular}

Model pengujian estimasi parameter dan interpretasi ini adalah model regresi logistik yang menghasilkan suatu persamaan data sebagai berikut.

$\mathrm{Ln} \frac{\mathrm{EM}}{1-\mathrm{EM}}=0,472+4,612 \mathrm{DTC}+6,262 \mathrm{DM}+5, \mathrm{~B} 7 \mathrm{CL} \mathrm{CHO}+\varepsilon$

Keterangan:

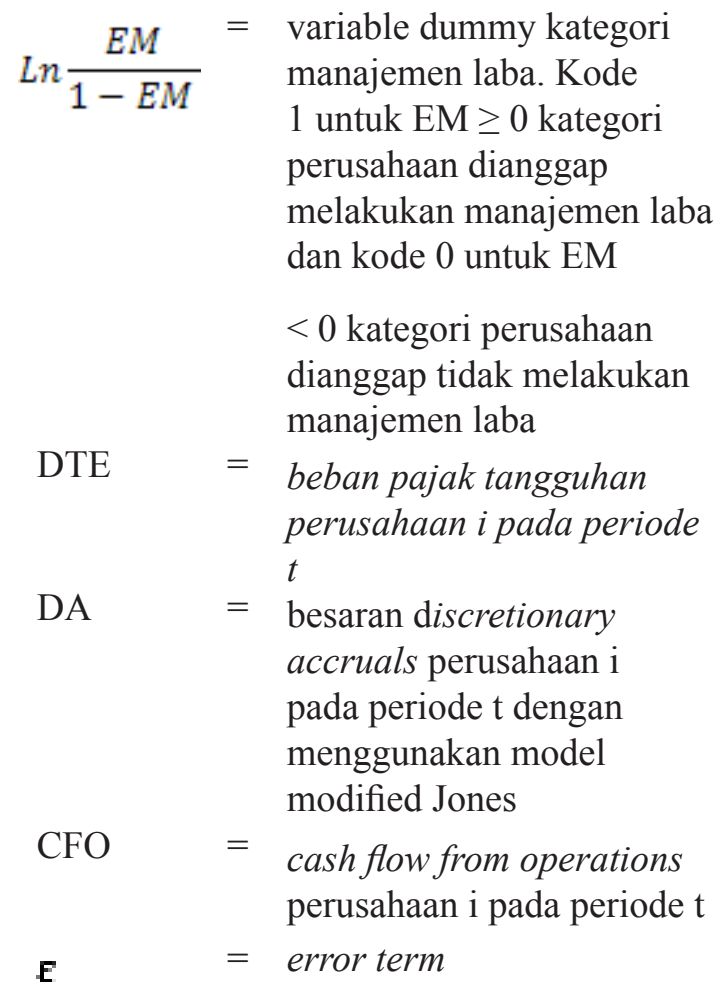

Beban pajak tangguhan memiliki tingkat signifikansi sebesar 0,478 yang berarti beban pajak tangguhan memiliki pengaruh yang tidak signifikan terhadap manajemen laba pada alpha 5\%. Variable discretionary accruals memiliki signifikansi sebesar 0,000 yang berarti bahwa discretionary accruals memiliki pengaruh signifikan terhadap manajemen laba pada alpha $5 \%$. Sedangkan arus kas operasi memiliki signifikansi sebesar 0,000 yang berarti bahwa arus kas operasi memiliki pengaruh signifikan terhadap manajemen laba pada alpha $5 \%$.

\section{Omnibus Test of Model Coefficient}

Model ini untuk menguji tingkat signifikansi variabel bebas secara bersama-sama memiliki pengaruh yang signifikan terhadap manajemen laba. Tabel 5 menunjukan bahwa chi-square memiliki tingkat signifikansi sebesar 0,000 yang berarti bahwa beban pajak tangguhan, discretionary accruals, dan arus kas operasi secara bersama-sama memiliki pengaruh yang signifikan terhadap manajemen laba.

6. Pengujian korelasi antar-variabel independen

Pengujian ini bertujuan untuk megetahui apakah terdapat korelasi antar-variabel independen. Tabel 6 menunjukkan bahwa

Tabel 4

Hasil Pengujian Estimasi Parameter dan Interpretasinya

\begin{tabular}{rlrrrrrrr}
\hline \multicolumn{8}{c}{ Variables in the Equation } \\
\hline & B & \multicolumn{1}{c}{ S.E. } & Wald & df & Sig. & Exp(B) \\
\hline \multirow{3}{*}{ Step 1 $^{\text {a }}$} & DTE & 4,612 & 6,501 &, 503 & 1 &, 478 & 100,666 \\
& DA & 6,262 & 1,417 & 19,533 & 1 &, 000 & 524,236 \\
& CFO & 5,871 & 1,275 & 21,210 & 1 &, 000 & 354,514 \\
& Constant &, 472 &, 111 & 17,999 & 1 &, 000 & 1,604 \\
\hline
\end{tabular}


Tabel 5

Omnibus Tests of Model Coefficients

\begin{tabular}{llrrr}
\hline & Chi-quare & df & \multicolumn{2}{c}{ Sig. } \\
\hline \multirow{2}{*}{ Step 1 } & Step & 34,877 & 3 &, 000 \\
& Block & 34,877 & 3 &, 000 \\
& Model & 34,877 & 3 &, 000 \\
\hline
\end{tabular}

korelasi antar-variabel masih di bawah 95\% sehingga dapat dikatakan tidak terjadi multikolinearitas.

\section{Kesimpulan}

Dari hasil penelitian, dan analisis data maka dapat diambil kesimpulan sebagai berikut.

1. Beban pajak tangguhan berpengaruh tetapi tidak signifikan terhadap tindakan manajemen laba yang dilakukan oleh perusahaan. Hubungan beban pajak tangguhan positif dengan tindakan manajemen laba memiliki arti bahwa semakin besar beban pajak tangguhan maka semakin besar probabilitas perusahaan melakukan tindakan manajemen laba.

2. Discretionary accruals berpengaruh signifikan terhadap manajemen laba serta memiliki hubungan yang positif antara discretionary accruals dengan manajemen laba yang artinya semakin besar discretionary accruals maka semakin besar peluang manajemen perusahaan melakukan tindakan manajemen laba.

3. Arus kas operasi berpengaruh signifikan terhadap tindakan manajemen laba yang dilakukan oleh perusahaan. Arus kas operasi memiliki hubungan positif terhadap manajemen laba yang artinya semakin besar arus kas operasi yang dimiliki perusahaan maka semakin besar peluang manajemen perusahaan melakukan tindakan manajemen laba.

4. Beban pajak tangguhan, discretionary accruals, dan arus kas operasi berpengaruh positif signifikan terhadap manajemen laba.

\section{Daftar Pustaka}

Barth, Mary E., et al, 2001. Accruals and The Prediction of Future Cash Flows, The Accounting Review, Vol. 76, No. 1:27-58.

Ghozali, Imam, 2014. Aplikasi Analisis Multivariate Dengan Program IBM SPSS 21 Update PLS Regresi, Edisi Ketujuh, Badan Penerbit Universitas Diponegoro, Semarang. Healy, Paul M. \& Wahlen, James Michael, 1999.

A Review Of The Earnings Management Literature And Its Implications For Standard Setting. Accounting Horizons, Vol. 13, No. 4:365-383.

Jensen, Michael C. \& Meckling, Willliam H., 1976. Theory of The Firm: Managerial Behavior, Agency Costs and Ownership Structure, Journal of Financial Economics, Vol. 3, No. 4:305-360.

Kieso, et al, 2013. Intermediate Accounting, Fifteenth Edition, John Wiley \& Sons, Inc., Hoboken, NJ.

Merchant, Kenneth A. \& Rockness, Joanne, 1994.

The Ethics of Managing Earnings, Journal of Accounting and Public Policy, Vol. 13, No.1:79-94.

Tabel 6

Korelasi Antar-Variabel Independen Correlation Matrix

\begin{tabular}{rlrrrr}
\hline & & Constant & \multicolumn{1}{c}{ DTE } & \multicolumn{1}{c}{ DA } & \multicolumn{1}{c}{ CFO } \\
\hline \multirow{4}{*}{ Step 1 } & Constant & 1,000 &, 074 &,- 348 &,- 238 \\
& DTE &, 074 & 1,000 &,- 097 &,- 091 \\
& DA &,- 348 &,- 097 & 1,000 &, 670 \\
& CFO &,- 238 &,- 091 &, 670 & 1,000 \\
\hline
\end{tabular}


Riahi-Belkaoui, Ahmed, 1999. Earnings Measurement, Determination, Management, and Usefulness, Greenwood Publishing Group, Inc.

Scott, William R., 2014. Financial Accounting Theory, Seventh Edition, Pearson Education, Canada.

Setiawati, L. \& Nai'm, 2000. Manajemen Laba, Jurnal Ekonomi dan Bisnis Indonesia, Vol. 15, No. 4:424-441.

Siregar, Silvia, 2008. Pengaruh Pertumbuhan Hutang dan Asimetri Informasi Terhadap Penilaian Pasar Atas Discretionary Accrual, Simposium Nasional Akuntansi XI, Pontianak.

Subagyo, et al, 2011. Pengaruh Discretionary Accrual dan Beban Pajak Tangguhan Terhadap Manajemen Laba, Jurnal Akuntansi, Vol. 11, No. 1:355-376.

Suranggane, Zulaikha, 2007. Analisis Aktiva Pajak Tangguhan dan Akrual Sebagai Prediktor Manajemen Laba, Jurnal Akuntansi dan Keuangan Indonesia, Vol. 4, No. 4:7794.

Wiryandari, Santi Aryn \& Yulianti, 2009. Hubungan Perbedaan Laba Akuntansi \& Laba Pajak Dengan Perilaku Manajemen Laba dan Persistensi Laba, Simposium Nasional Akuntansi XII, Palembang.

Yulianti, 2005. Kemampuan Beban Pajak Tangguhan Dalam Mendeteksi Manajemen Laba, Jurnal Akuntansi dan Keuangan Indonesia, Vol. 2, No. 1:107-129. 